\title{
Optimal Blood Pressure in Preterm Infants
}

Hyun-Kyung Park, M.D., Ph.D.

Department of Pediatrics, Hanyang University College of Medicine, Seoul, Korea

\section{Abstract}

Received: 18 April 2014

Revised: 26 April 2014

Many neonatologists routinely treat infants whose mean arterial blood pressure in $\mathrm{mm} \mathrm{Hg}$ is less than their gestational age in weeks (GA) but there is uncertainty regarding diagnosis and treatment of hypotension. This addresses the definition of permissive hypotension based on the principles of cardiovascular physiology, and reviews the tools available at the bedside to examine the complex relationship among blood pressure, systemic organ blood flow, and tissue oxygen delivery and oxygen demand in preterm infants (skin color, capillary refill time, urine output, serum lactate level, and acidosis). Importantly, absolute blood pressure values are only one indicator of circulatory status and this review confirms that a mean blood pressure less than gestational age in weeks alone is not a predictor of poor outcome. Global assessment of cardiovascular status and intervention for hypotension restricted to infants with poor perfusion may be associated with good clinical outcomes and should be further evaluated.

Key Words: Hypotension, Preterm infant, Systemic blood flow, Echocardiography

\section{INTRODUCTION}

Hypotension is a commonly diagnosed and treated complication in preterm infants, but enormous variation in diagnosis, management, and clinical practice has been documented ${ }^{1)}$. In extremely low gestational age newborns, the majority of neonatologists (73\%) defines hypotension as a mean blood pressure in $\mathrm{mmHg}$ less than the gestational age in weeks ${ }^{2)}$. The majority $(85 \%)$ uses volume administration as the initial intervention and dopamine is the inotrope most commonly used initially ( $80 \%$ of cases $)^{1,3)}$. If the initial inotrope therapy fails, dobutamine is the most popular second-line therapy ( $28 \%$ of cases $)^{4)}$.

In preterm infants during the first days of life, there is a poor association between blood pressure and systemic blood flow, with some data even showing an inverse correlation in the first hours after birth ${ }^{5}$. Low superior vena cava (SVC) flow is a risk factor for mortality and morbidity in preterm infants, but hypotension itself is not reliable in detecting low systemic blood flow ${ }^{6-8}$. Functional echocardiography allows assessment of cardiovascular status, including measurement of systemic blood flow in preterm infants ${ }^{9}$.

\footnotetext{
Copyright(c)

By Korean Society of Neonatology.

All right reserved.

This is an Open-Access article distributed under the terms of the Creative Commons Attribution Non-Commercial License (http://creativecommons.org/licenses/ by-nc/3.0), which permits unrestricted non-commercial use, distribution, and reproduction in any medium, provided the original work is properly cited.
}

Hyun-Kyung Park, M.D., Ph.D.

Department of Pediatrics, Hanyang 17 Haengdang-dong, Seongdonggu, Seoul 133-792, Korea

Tel: +82-2-2290-8397

Fax: +82-2-2297-2380

E-mail:neopark@hanyang.ac.kr 
Without understanding the underlying cardiovascular principles of transition, appropriate interventional trials cannot be designed. Therefore, more comprehensive monitoring and assessment of systemic blood flow and tissue oxygenation must be explored in preterm infants.

\section{DEFINITION OF HYPOTENSION IN PERTERM INFANTS}

Hypotension is defined in clinical trials and in practice as any value that falls below the fifth or tenth percentile for gestational and postnatal age, respectively ${ }^{2}$. Although acceptable blood pressure ranges are not known for the extremely low birth weight (ELBW) infant, many neonatologists routinely treat infants whose mean arterial blood pressure is less than their gestational age in weeks ${ }^{10)}$.

Hypotension occurs in approximately $50 \%$ of very low birth weight infants admitted to the intensive care unit. Three levels of compromised cerebral blood flow ( $\mathrm{CBF}$ ) may also be used to define hypotension (Figure 1) ${ }^{2,11)}$. Furthermore, the absolute blood pressure values at which these thresholds occur are ill-defined and likely to vary among individual patients and the underlying pathological processes. Thus, the clinical definition of hypotension and a selected group such as very preterm infants (not the physiological definition itself) should be considered(Figure 1) $)^{2}$.

We do not know the mean arterial blood pressure value at

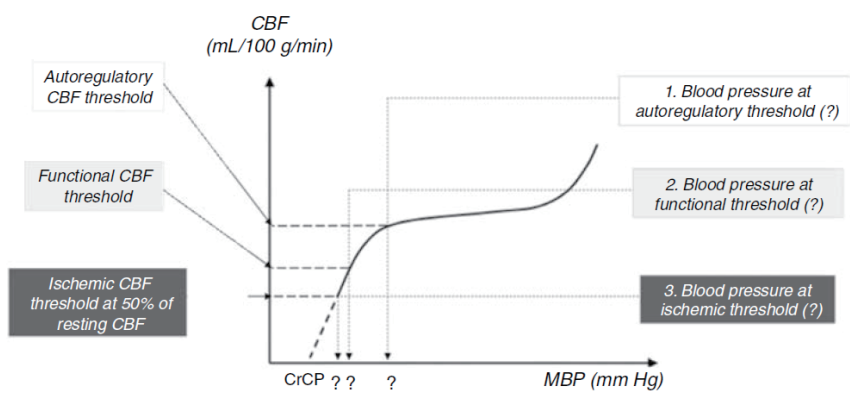

Figure 1. Definition of hypotension by three pathophysiological phenomena of increasing severity: the 'autoregulatory, functional and ischemic thresholds' of hypotension. Cerebral cellular function and structural integrity are not affected at the 'autoregulatory threshold' and cerebral function becomes compromised at the 'functional blood pressure threshold' and finally, structural integrity is compromised at the 'ischemic blood pressure threshold. Autoregulation is limited and 'ischemic blood pressure threshold', that is likely to vary with the level of maturity, is unknown in preterm infants. CBF, cerebral blood flow; MBP, mean blood pressure; $\mathrm{CrCP}$, critical closing pressure. From Cayabyab R, et al. J Perinatol 2009; 29:S58-62 [2]. which cerebrovascular autoregulation is lost in the preterm infant, although recent studies suggest that it may be as high as 28 to 30 mmHg even in ELBW infants ${ }^{12}$. There is an association between the loss of autoregulation, the resultant CBF fluctuations, and morbidity and mortality in preterm infants ${ }^{13)}$.

In animal models, the ischemic blood pressure threshold is reached when the corresponding CBF is approximately $50 \%$ of the resting $\mathrm{CBF}^{14)}$. However, the "ischemic blood pressure threshold" is unknown in preterm neonates and is likely to vary with the level of maturity, intercurrent or pre-existing pathophysiological conditions and physiological variables such as $\mathrm{pH}, \mathrm{PaCO}_{2}$, and $\mathrm{PaO}_{2}$.

\section{ASSESSMENT OF HEMODYNAMICS BY ECHOCARDIOGRAPHY}

The use of functional echocardiography in recent prospective clinical trials has contributed to our better understanding of the hemodynamic changes associated with postnatal transition ${ }^{2,14)}$. Although there is no evidence that its use is associated with better outcomes, it provides a more accurate assessment of the pathophysiology of cardiovascular compromise and is likely to become an essential part of the hemodynamic evaluation of preterminfants (Table 1$)^{15}$.

The left ventricular (LV) ejection fraction (EF) and fractional shortening (FS) are commonly used to estimate LV systolic function, although EF and FS are largely influenced by preload, afterload, and heart rate ${ }^{15)}$. Thus, these load-dependent indices cannot be reliably used to evaluate cardiac function in the unstable circulation of infants shortly after birth. Instead, an index known as the "stress-velocity relationship" has been used clinically for ill infants as a sensitive and relatively load-independent index. This index is calculated from the end-systolic wall stress (ESWS), which is an index of $\mathrm{LV}$ afterload, and the LV rate-corrected mean velocity of circumferential fiber shortening (mVcfc), which is an index of LV pump function. ESWS is calculated from blood pressure values and LV dimensions by echocardiographic measurement, and $\mathrm{mVcfc}$ is calculated from the LV FS, ejection time, and heart rate (Table 1, Figure 2).

\section{HYPOTENSION AND SYSTEMIC PERFUSION}

Preterm infants with a mean arterial blood pressure lower 
than their gestational age in weeks often have no clinical signs of shock, presumably have adequate tissue oxygen delivery, and may therefore not need treatment ${ }^{16)}$.

The principal role of the circulation is to ensure adequate delivery of oxygen and nutrients to tissues so that their metabolic demand and is achieved by maintaining appropriate perfusion pressure and cardiac output (CO) in the systemic and pulmonary circulations demand ${ }^{9)}$. In the systemic circulation, the interaction between $\mathrm{CO}$ and systemic vascular resistance (SVR) regulates $\mathrm{BP}$ according to the relationship: $\mathrm{BP}=\mathrm{CO} \times \mathrm{SVR}$ (Figure 3 ). However, in clinical practice, we rely primarily on the information obtained from BP monitoring and, at present, cannot routinely assess the changes in CO and/or SVR when hypotension and/or cardiovascular compromise are diagnosed and treated ${ }^{10)}$.

As maintenance of cardiovascular wellbeing is complicated, neonatologists try to assess continuous heart rate, $\mathrm{BP}$, arterial oxygen saturation monitoring, and continuous $\mathrm{CO}$ monitoring with or without assessment of the SVR together (Figure 3) ${ }^{9}$. Under the circumstance of neonatal shock, its early "compensated phase" shows that blood flow and oxygen delivery are maintained to the vital organs (brain, heart, and adrenal glands) ${ }^{17)}$. The vessels of vital organs vasodilate when perfusion pressure decreases (highpriority), whereas the vessels of non-vital organs respond with vasoconstriction to a decrease in BP (low-priority). Recently, near infrared spectroscopy (NIRS) can monitor, in real-time, the vital and non-vital organ mixed venous tissue oxygen saturation ${ }^{18)}$.

Laboratory indices of perfusion, such as serum lactate and acidosis (base excess) during anaerobic metabolism, frequently used in the diagnosis of poor tissue perfusion (Table 1). Especially, lactate values have been analyzed in a number of clinical situations in the preterm infant and elevated values on the first day of postnatal life are associated with increased mortality in preterm and term newborns ${ }^{19)}$. In contrast, Wardle et $\mathrm{al}^{20)}$

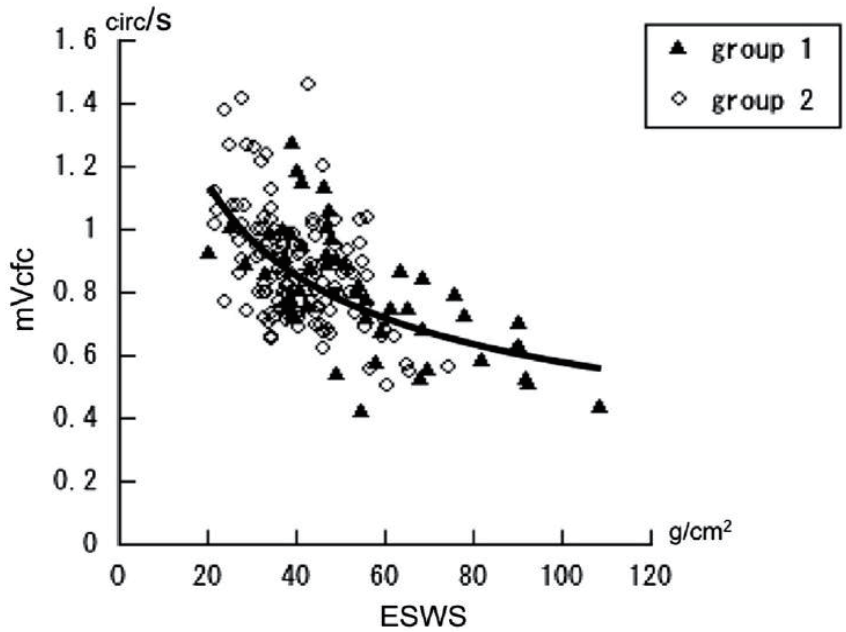

Figure 2. Stress-velocity relationship [mVcfc (an index of LV pump function) - ESWS (an index of LV afterload) relationship]. The changes in mVcfc were opposite to the changes in ESWS. There were significant correlations between ESWS and mVcfc in both groups $\left(\mathrm{mVcfc}=3.76 \times \mathrm{ESWS}^{-0.4} ; P<0.01, \mathrm{R}=0.56\right)$. Group 1 : infants with complications (pulmonary hemorrhage, intraventricular hemorrhage, and periventricular leukomalacia; $n=9$ ). Group 2: infants without complications $(n=24)$. Systolic blood pressure (sBP) and mean blood pressure (mBP) changed over time, with no differences between the groups. This indicates that the LV pump function of preterm infants can easily be suppressed by a subtle increase in afterload, causing reduced cardiac output. mVcfc, mean velocity of circumferential fiber shortening; ESWS, end-systolic wall stress; LV, left ventricle. From Toyoshima K, et al. J Formos Med Assoc. 2013;112:510-7 [15].

Table 1. Assessment of Cardiovascular Function and Organ Perfusion in Preterm Infants at the Bedside. From Toyoshima K, et al. J Formos Med Assoc 2013;112:510-7 [15].

\begin{tabular}{|c|c|}
\hline Vital signs & HR, BP, urine \\
\hline Blood examination & lactic acid, BNP (brain natriuretic peptide), BE (base excess) \\
\hline \multirow[t]{11}{*}{ Echocardiography } & Preload \\
\hline & LVIDd (left ventricle internal diameter in diastole) \\
\hline & LA volume; LA (left atrium) / Ao (aorta) \\
\hline & Afterload \\
\hline & ESWS (end-systolic wall stress) \\
\hline & Pump function \\
\hline & EF (ejection fraction) \\
\hline & FS (fractional shortening) \\
\hline & mVcfc (mean velocity of circumferential fiber shortening) \\
\hline & PDA : shunt assessment \\
\hline & Cardiac output : SVC (superior vena cava) flow \\
\hline
\end{tabular}


found no difference in lactate levels between normotensive and hypotensive preterm infants. Correlation between lactate values with systemic blood flow was improved by combining capillary filling time; lactate $>4 \mathrm{mmol} / \mathrm{L}$ plus prolonged capillary refill times $>4 \mathrm{~s}$ showed high positive predictive value $(80 \%)$ and negative predictive value (88\%) for identifying low SVC flow. This highlights the importance of combining clinical and biochemical parameters in the assessment of the adequacy of end-organ blood flow $^{8,9)}$.

\section{PERMISSIVE HYPOTENSION IN ELBW INFANTS}

Global assessment of cardiovascular status includes assessment of other easily evaluable physical observations including capillary refill, skin color, heart rate, urine output, level of activity, and biochemical observations, in particular the degree of acidosis ${ }^{10)}$.
Although this assessment of the adequacy of end-organ perfusion is crude and not infallible, and each finding taken in isolation may be a poor indicator of perfusion, together they may provide more information than absolute blood pressure values alone. There is no evidence that attempts to achieve a "normal" blood pressure based on absolute reference values will improve outcomes, and the therapies available may be potentially toxic or dangerous.

Dempsey et $\mathrm{al}^{10)}$ evaluated this approach in ELBW infants in the first $72 \mathrm{~h}$ of life and patients were grouped as either normotensive (BP never less than gestational age), hypotensive untreated (BP less than gestational age but with signs of good perfusion; we termed this "permissive hypotension"), or hypotensive treated (BP less than gestational age with signs of poor perfusion). Blood pressure spontaneously improved in ELBW infants during the first $24 \mathrm{~h}$ and the outcome of infants hypotensive by gestational age criteria but with clinical evidence of good perfusion was as good as that of normotensive patients.

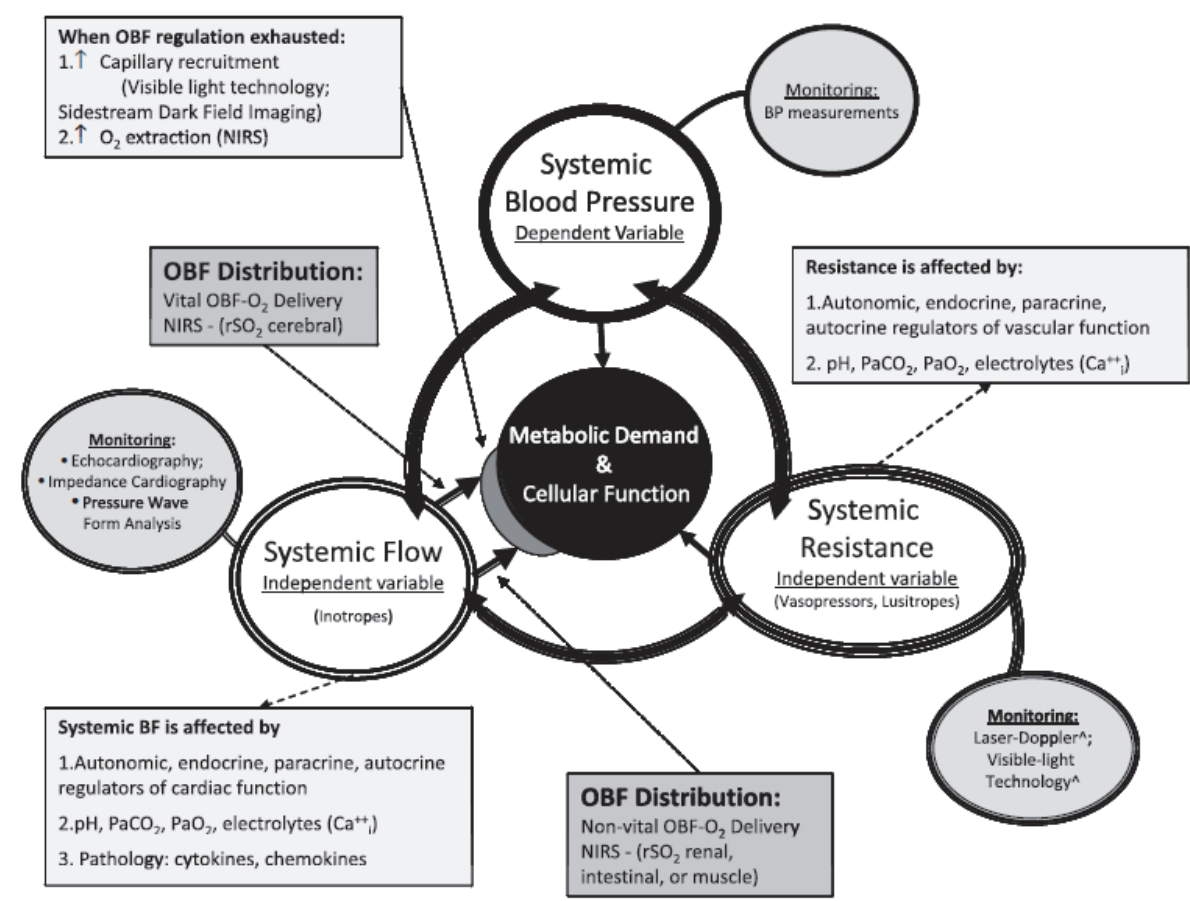

Figure 3. Interaction among and monitoring of blood pressure (BP), blood flow, blood flow distribution and systemic vascular resistance (SVR). To satisfy cellular metabolic demand, the intricate relationship among blood flow, vascular resistance, and BP takes place. Regulation of organ blood flow distribution, capillary recruitment and oxygen extraction is also essential for the maintenance of hemodynamic homeostasis. Among these three fundamental factors determining basic cardiovascular function, cardiac output (CO) and SVR are the independent variables that are regulated by the body and BP is the dependent variable by the two independent variables. Abbreviations: CBF, cerebral blood flow; NIRS, near infrared spectroscopy; OBF, organ blood flow; rSO2, regional tissue oxygen saturation. From Soleymani S, et al. J Perinatol 2010;30:S38-45 [9]. 


\section{THERAPEUTIC APPROACHES TO HYPOTENSION}

The stress-velocity relationship showed a steep slope in the low ESWS range, as seen in Figure $2^{15,21)}$. The ESWS or afterload is lower in younger age groups than in older age groups. Therefore, the cardiac pumping function is easily impaired and $\mathrm{mVcfc}$ is easily decreased by even a small increase in afterload or ESWS in smaller or younger infants with low ESWS. All previous reports on the stress-velocity relationship relate to preterm infants who were not treated with circulatory agonists, and there have been no reports on the changes in these parameters in preterm infants treated with catecholamines.

Central venous pressure (CVP) monitoring is not practical in the circulatory management of preterm infants. In CVP monitoring, emphasis is placed largely on blood pressure. However, an increase in cardiac preload or venous pressure due to excessive afterload cannot be predicted by blood pressure or urine volume alone ${ }^{15)}$. The aim of circulatory management in preterm infants should be to avoid the increase in venous pressure caused by excessive afterload.

Toyoshima et $\mathrm{al}^{15)}$ investigated how circulatory agonists affect excessive afterload and evaluated the changes in the stressvelocity relationship prior to and after the use of dobutamine and a vasodilator nitroglycerin in very low birth weight infants. Dobutamine, at a dose of $4 \mathrm{mg} \cdot \mathrm{kg}^{-1} \cdot \mathrm{min}^{-1}$, increased blood pressure in all infants. However, the stress-velocity relationship showed that the cardiac pump function improved in only half of the infants, whereas ESWS increased and cardiac pump function deteriorated in the other half. Dobutamine did not clearly improve low mVcfc, particularly when ESWS increased. By contrast, a dose of $0.5-1.5 \mathrm{mg} \cdot \mathrm{kg}^{-1} \cdot \mathrm{min}^{-1}$ nitroglycerin, which was used for elevated ESWS, reduced ESWS and increased mVcfc.

Dempsey et $\mathrm{al}^{22)}$ recently established the HIP (Hypotension in Preterm Infants) Consortium, comprising neonatologists, scientists, pharmacologists and industry partners (Figure 4) to provide assessment protocols for determining when we should treat hypotension in the extremely preterm babies ( $<28$ weeks of gestation) and in using the most commonly used dopamine.

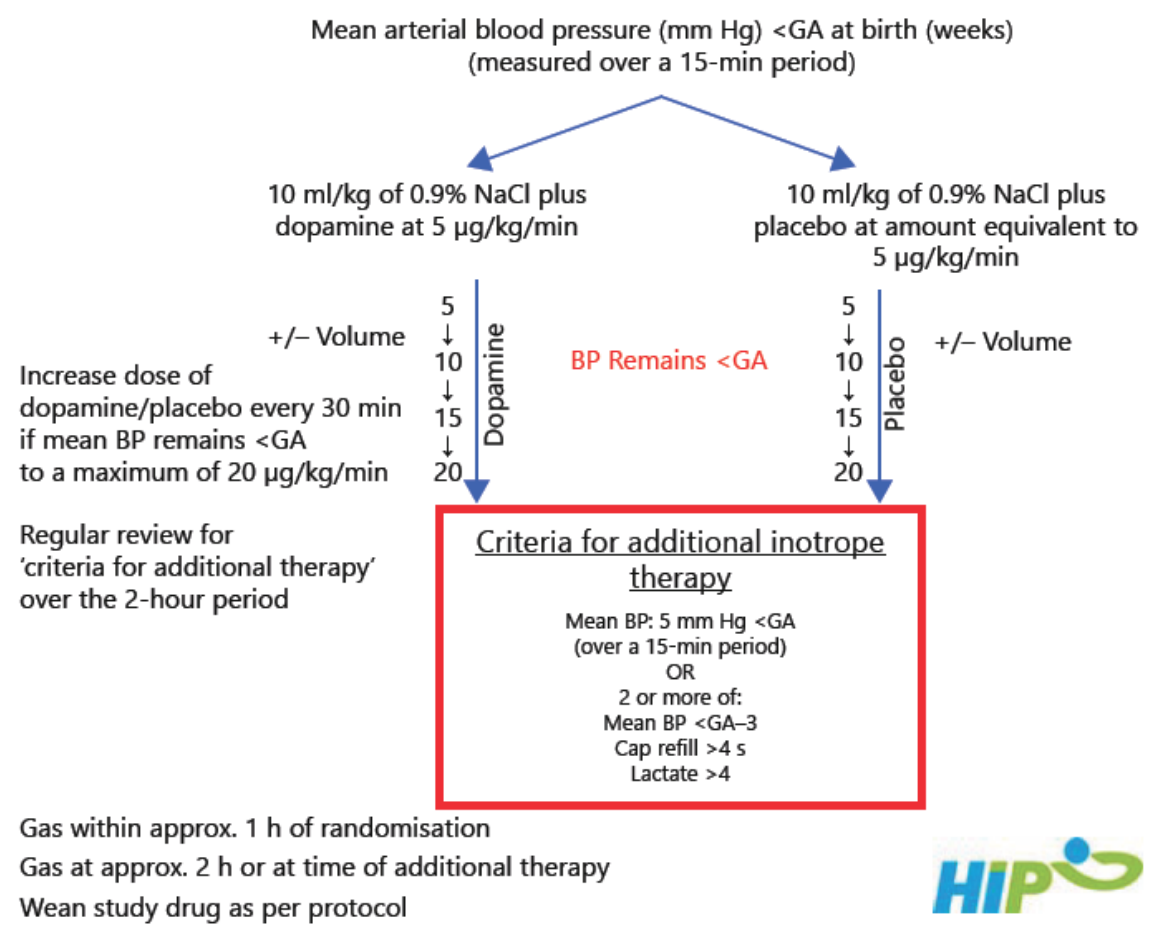

Figure 4. Treatment algorithm for the management of low BP in extremely preterm infants during the first $72 \mathrm{~h}$ of life; The HIP (hypotension in preterm infant) Trial. HIP is designed to evaluate two strategies in a randomized controlled trial, and define the efficacy of the most commonly used inotropic medication, dopamine. From Dempsey EM, et al. Neonatol 2014;105:275-81 [22]. 


\section{CONCLUSION}

In a neonatal intensive care setting, many extremely preterm infants receive treatment for hypotension, but a blood pressure less than the gestational age does not necessarily need to be treated. Global assessment of cardiovascular status and intervention for hypotension restricted to infants with poor perfusion (skin color, capillary refill rate, urine output, blood lactate level, and acidosis) may have good clinical outcomes ${ }^{10,16,23)}$. Prospective randomized studies of clinical outcomes with standard versus restricted treatment of hypotension are essential.

\section{REFERENCES}

1) Stranak Z, Semberova J, Barrington $K$, O'Donnell C, Marlow $\mathrm{N}$, Naulaers G, et al. International survey on diagnosis and management of hypotension in extremely preterm babies. Eur J Pediatr 2014 Jan 4. doi:10.1007/s00431-013-2251-9.

2) Cayabyab R, McLean CW, Seri I. Definition of hypotension and assessment of hemodynamics in the preterm neonate. $\mathrm{J}$ Perinatol 2009;29 Suppl 2:S58-62.

3) Batton B, Li L, Newman NS, Das A, Watterberg KL, Yoder BA, et al. Use of antihypotensive therapies in extremely preterm infants. Pediatrics 2013;131:e1865-73.

4) Osborn DA, Paradisis M, Evans N. The effect of inotropes on morbidity and mortality in preterm infants with low systemic or organ blood flow. Cochrane Database Syst Rev 2007: CD005090. doi: 10.1002/14651858.CD005090.pub2.

5) Groves AM, Kuschel CA, Knight DB, Skinner JR. Relationship between blood pressure and blood flow in newborn preterm infants. Arch Dis Child Fetal Neonatal Ed 2008;93:F29-32.

6) Shah DM, Condò M, Bowen J, Kluckow M. Blood pressure or blood flow: which is important in the preterm infant? a case report of twins. J Paediatr Child Health 2012;48:E144-6.

7) Kluckow M, Evans N. Low superior vena cava flow and intraventricular haemorrhage in preterm infants. Arch Dis Child Fetal Neonatal Ed 2000;82:F188-94.

8) Miletin J, Dempsey EM. Low superior vena cava flow on day 1 and adverse outcome in the very low birthweight infant. Arch Dis Child Fetal Neonatal Ed 2008;93:F368-71.

9) Soleymani S, Borzage M, Seri I. Hemodynamic monitoring in neonates: advances and challenges. J Perinatol 2010;30 Suppl:
S38-45.

10) Dempsey EM, Al Hazzani F, Barrington KJ. Permissive hypotension in the extremely low birthweight infant with signs of good perfusion. Arch Dis Child Fetal Neonatal Ed 2009;94: F241-4.

11) Azhan A, Wong FY. Challenges in understanding the impact of blood pressure management on cerebral oxygenation in the preterm brain. Front Physiol 2012;3:471. doi: 10.3389/fphys. 2012.00471.

12) Munro MJ, Walker AM, Barfield CP. Hypotensive extremely low birth weight infants have reduced cerebral blood flow. Pediatrics 2004;114:1591-6.

13) Tsuji M, Saul JP, du Plessis A, Eichenwald E, Sobh J, Crocker R, et al. Cerebral intravascular oxygenation correlates with mean arterial pressure in critically ill premature infants. Pediatrics 2000;106:625-32.

14) Greisen G. Autoregulation of cerebral blood flow in newborn babies. Early Hum Dev 2005;81:423-8.

15) Toyoshima K, Kawataki M, Ohyama M, Shibasaki J, Yamaguchi N, Hoshino R, et al. Tailor-made circulatory management based on the stress-velocity relationship in preterm infants. J Formos Med Assoc 2013;112:510-7.

16) Ahn SY, Kim ES, Kim JK, Shin JH, Sung SI, Jung JM, et al. Permissive hypotension in extremely low birth weight infants ( $\leq 1000$ gm). Yonsei Med J 2012;53:765-71.

17) Noori S, Stavroudis TA, Seri I. Systemic and cerebral hemodynamics during the transitional period after premature birth. Clin Perinatol 2009;36:723-36.

18) van BelF, Lemmers $P$, Naulaers G. Monitoring neonatal regional cerebral oxygen saturation in clinical practice: value and pitfalls. Neonatology 2008;94:237-44.

19) Groenendaal F, Lindemans C, Uiterwaal CS, de Vries LS. Early arterial lactate and prediction of outcome in preterm neonates admitted to a neonatal intensive care unit. Biol Neonate 2003; 83:171-6.

20) Wardle SP, Yoxall CW, Weindling AM. Peripheral oxygenation in hypotensive preterm babies. Pediatr Res 1999;45:343-9.

21) Takahashi Y, Harada K, Kishkurno S, Arai H, Ishida A, Takada G. Postnatal left ventricular contractility in very low birth weight infants. Pediatr Cardiol 1997;18:112-7.

22) Dempsey EM, Barrington KJ, Marlow N, O'Donnell CP, Miletin J, Naulaers G, et al. Management of hypotension in preterm infants (The HIP Trial): a randomised controlled trial of hypotension management in extremely low gestational age newborns. Neonatology 2014;105:275-81.

23) Alderliesten T, Lemmers PM, van Haastert IC, de Vries LS, Bonestroo HJ, Baerts W, et al. Hypotension in preterm neonates: low blood pressure alone does not affect neurodevelopmental outcome. J Pediatr 2014 Jan 28. doi: 10.1016/j.jpeds.2013.12.042. 


\section{미숙아에서의 적정 혈압}

한양대학교 의과대학 소아과학교실

박현경

대부분의 신생아 의사들은 미숙아에서의 저혈압을 치료함에 있어, 재태기간 수치와 비교하여 그보다 낮은 평균 동맥압 을 보이는 경우를 대상으로 하지만, 그 진단 및 치료에 있어서는 모호한 상황이다. 저자는 심혈관계 생리를 근거로 한 미숙아에서의 permissive hypotension의 개념을 살펴보고, 혈압과 더불어 기관으로의 혈류 및 조직으로의 산소 전달 간 의 복잡한 관계를 규명할 수 있는 검사 방법 및 조직의 산소 요구량을 임상적 측면에서 검토하고자 한다. 절대적 혈압 수치는 단지 순환계 상태를 나타내는 하나의 지표에 지나지 않으며, 재태기간보다 낮은 평균 혈압으로는 예후를 예측 하지 못함을 강조한다. 포괄적인 심혈관계 상태의 판단 및 조직 관류 상태에 근거한 적절한 저혈압 치료만이 좋은 임상 적 경과를 나타낼 것으로 사료되며, 향후 심도있는 연구가 요구된다. 